\title{
NUEVAS APORTACIONES SOBRE EL ESCULTOR COSME VELÁZQUEZ
}

(1755-1837)

\author{
MYRIAM FERREIRA FERNÁNDEZ \\ UNIVERSIDAD INTERNACIONAL DE LA RIOJA
}

\begin{abstract}
RESUMEN: El escultor logroñés Cosme Velázquez fue una figura destacadas del arte en Cádiz entre los siglos XVIII y XIX. Fue un artista fecundo que participó en muchas obras realizadas en la ciudad y trabajó como profesor de escultura de la Escuela de Nobles Artes de Cádiz, transmitiendo el estilo academicista que él había adquirido en la Real Academia de Bellas Artes de San Fernando. Este artículo añade nuevos datos sobre su infancia y juventud, así como la atribución de una nueva obra en la localidad riojana de Navarrete, que ayuda a perfilar aún más el estilo artístico de este escultor.
\end{abstract}

PALABRAS ClAVE: Cosme Velázquez, escultura, academicismo, Cádiz, Navarrete.

\section{NEW CONTRIBUTIONS TO THE SCULPTOR COSME VELÁZQUEZ}

(1755-1837)

\begin{abstract}
The sculptor Cosme Velázquez, born in Logroño (La Rioja), was an important artist who lived in Cádiz during the XVIII ${ }^{\text {th }}$ and XIX $^{\text {th }}$ centuries. He worked in a large number of sculptures of that city and he taught at the Fine Arts School of Cádiz, where he transmitted the academic style that he has learned in the Royal Academy of Fine Arts of Madrid. This article adds new information about his childhood and youth. Besides, it introduces a new work placed in Navarrete (La Rioja), which helps to know better the artistic style of this sculptor.
\end{abstract}

KEYWORDS: Cosme Velázquez, sculpture, academicism, Cádiz, Navarrete.

Recibido: 21-04-2015 / Aceptado: 02-10-2015 
Cosme Velázquez fue un escultor logroñés que alcanzó renombre por su actividad artística en la ciudad de Cádiz. Formado en la Real Academia de Bellas Artes de San Fernando, Cosme se convirtió en una figura señera del neoclasicismo gaditano, estilo que aplicó a sus obras y que difundió siendo profesor en la Escuela de Bellas Artes de Cádiz.

La figura de Cosme Velázquez ha sido estudiada en diferentes artículos y publicaciones dedicados tanto al arte academicista como, sobre todo, al arte en Cádiz en la transición del siglo XVIII al XIX ${ }^{1}$. Sin embargo, hay algunos aspectos sobre su figura que hasta ahora no se conocían o sobre los que no se disponía de datos suficientes. Con este artículo vamos a intentar aportar algunos datos complementarios sobre este escultor, basándonos en documentación existente tanto en La Rioja, su región natal, como en Madrid (Archivo de la Real Academia de Bellas Artes de San Fernando, Archivo General de Palacio) o Cádiz (Archivo Histórico Provincial), que esperamos que puedan servir para conocer mejor la vida y obra de este escultor.

\section{NACIMIENTO Y JUVENTUD DE COSME VELÁZQUEZ EN LOGROÑO}

Cosme Velázquez nació en Logroño el 27 de septiembre de 1755, hijo de Francisco Javier Velázquez e Isabel Merino. Sus abuelos paternos eran Juan Velázquez y María Antonia de Muro y sus abuelos maternos Francisco Merino y Catalina Chalar².

\footnotetext{
1 SERRANO FATIGATI, Enrique, Escultura en Madrid desde la segunda mitad del siglo XVI hasta nuestros días, Madrid, Hauser y Menet, 1912; PARDO CANALÍS, Enrique, Escultores del siglo XIX, Madrid, Instituto Diego Velázquez de Arte, 1951; SANCHO DE SOPRANIS, Hipólito, “Algunas noticias para la biografía de Cosme Velázquez”, Información del Lunes, 2 y 9-12-1957; OROZCO ACUAVIVA, Antonio, Orígenes de la Academia de Nobles Artes de Cádiz y artistas de su tiempo, Cádiz, Imprenta Narváez, 1973; PARDO CANALÍS, Enrique, "Cosme Velázquez, escultor de cámara honorario", Berceo, 18 (1951), pp. 43-50. Disponible en http://dialnet.unirioja.es/descarga/articulo/61081.pdf (consultado a 11/02/2015); MELENDRERAS GIMENO, José Luis, “Cosme Velázquez, director de escultura en la Escuela de Bellas Artes de Cádiz”, Gades, 11 (1983), pp. 249-253; BANDA Y VARGAS, Antonio de la, "El Academicismo de las Artes figurativas gaditanas", Archivo Español de Arte, 226 (1984), pp. 129-140; BANDA Y VARGAS, Antonio de la, "Evocación del escultor Cosme Velázquez en el CL aniversario de su muerte", Anales de la Academia de Bellas Artes de Cádiz, 6 (1988), pp. 19-31; GASCÓN HEREDIA María Teresa, Estudio bistórico de la Escuela de Nobles Artes de Cádiz. 1789-1842, Cádiz, Real Academia de Bellas Artes, 1989; AZCUE BREA, Leticia, La escultura en la Real Academia de Bellas Artes de San Fernando: catálogo y estudio, Madrid, Real Academia de Bellas Artes de San Fernando, 1994, p. 262; ALONSO DE LA SIERRA FERNÁNDEZ, Juan y Lorenzo, "Trabajos en yeso de Cosme Velázquez y su círculo para el Oratorio de la Santa Cueva", PH: boletín del Instituto Andaluz del Patrimonio Histórico, 33 (2000), pp. 76-86. Disponible en http://www.iaph.es/revistaph/index.php/revistaph/article/view/1089/1089\#.VNzL5PmG9qU (consultado a $11 / 02 / 2015)$.

2 AHDL, Logroño, Santiago el Real, Libro $8^{\circ}$ de Bautizados (1749-1758), fol. 193 v.
} 


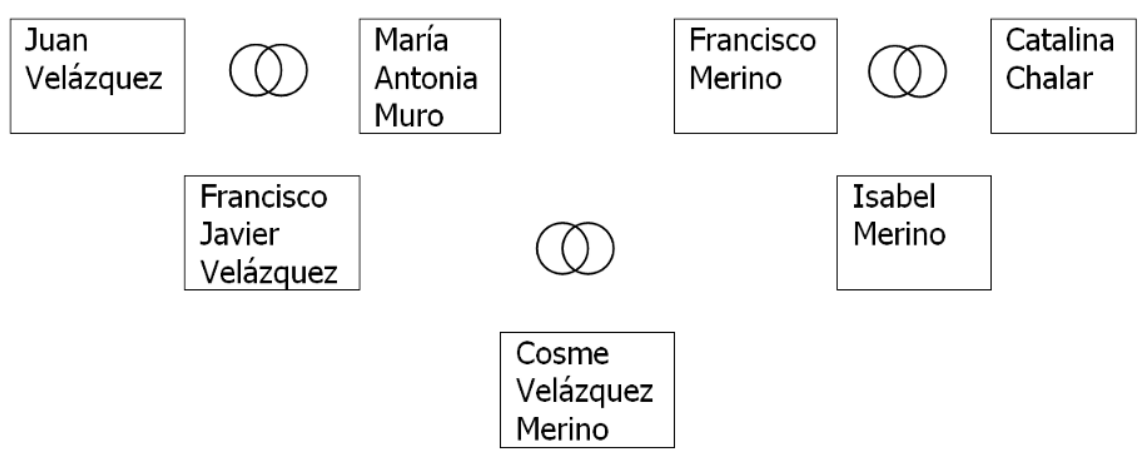

Gráfico 1. Árbol genealógico de los ascendientes de Cosme Velázquez

La fecha de su nacimiento había sido ya aportada por Antonio de la Banda. Sin embargo, a falta de más información sobre la infancia y juventud de Cosme, Banda realizaba algunas suposiciones basándose en los datos conocidos sobre este escultor. En este sentido, suponía que tal vez su familia tuviera cierta tradición artística, lo que le habría influido al elegir el oficio de escultor, que tal vez Cosme hubiera recibido cierta educación artística en Logroño antes de trasladarse a Madrid y que su familia debía ser adinerada para permitirse la estancia de Cosme en Madrid $^{3}$. Sin embargo, aunque estas suposiciones están planteadas con bastante lógica, lo cierto es que no parece que se correspondan con la realidad.

El oficio de los padres de Cosme Velázquez se puede conocer gracias al Catastro de Ensenada, realizado en Logroño en 1751, es decir, 4 años antes del nacimiento de Cosme. En él, podemos encontrar información tanto sobre su padre, Francisco Javier Velázquez, como sobre su abuelo materno, Francisco Merino.

Francisco Javier Velázquez tenía en 1751 cuarenta años, y aún estaba soltero. Trabajaba en el convento de Madre de Dios, un convento de franciscanas situado a las afueras de la localidad, donde era labrador y además administraba la hacienda de las religiosas. Vivía en una casa situada en el interior del propio convento, y las religiosas le proporcionaban, además del alojamiento, la manutención y un sueldo anual de 264 reales de vellón, una cantidad no muy elevada ${ }^{4}$.

En cuanto a Francisco Merino, era vecino de Logroño, de 42 años de edad, casado y con dos hijas menores, una de las cuales probablemente sería Isabel. Era jornalero, así que trabajaba los días que era llamado para desempeñar labores, cobrando solamente esos días una cantidad de 4 reales diarios, "y esto no es seguro, y de estos

3 BANDA Y VARGAS, Antonio de la, “Evocación del escultor Cosme Velázquez...”, pp. 20-21.

4 AHPLR, Catastro de Ensenada, Logroño, Memoriales de seglares, vol. 402, fol. 462 r. y v. 
mantengo a mi familia", se quejaba. Vivía en una casa arrendada en la calle Cerrada. No sabía leer ni escribir ${ }^{5}$.

Así que, según los datos del Catastro, no existen precedentes de artistas en la familia de Cosme Velázquez, al menos en el entorno más cercano. Tampoco parece que su familia poseyera una gran educación: aunque su padre sí debía de saber leer y escribir, así como algo de cálculo para llevar la administración de las religiosas del convento de Madre de Dios, su abuelo materno era analfabeto. Ni tampoco se trataba de una familia especialmente adinerada, más bien al contrario, era una familia muy humilde. De hecho, a lo largo de la biografía de Cosme veremos cómo su situación económica, al menos hasta su llegada a Cádiz, será más bien precaria.

Finalmente, respecto a la posibilidad de que hubiera recibido una formación artística en Logroño antes de trasladarse a la Real Academia, hasta ahora no hemos encontrado ninguna carta de aprendizaje a su nombre entre los protocolos notariales del Archivo Histórico de Logroño. Banda suponía esta formación previa basándose en que 18 años era una edad bastante elevada para inscribirse en la Real Academia, pero en estos primeros años de la institución era bastante habitual entrar en la Real Academia a esas edades: por ejemplo, a modo de muestra podemos fijarnos en los otros tres jóvenes que figuran, junto con Cosme, en la letra C de los inscritos en la Academia en 1773, y vemos que aunque Carlos Espinosa tenía 15 años, Carlos José Gierte tenía también 18 años y Carlos Montangis tenía ya 21 años ${ }^{6}$.

Banda también apoyaba su suposición en el hecho de que se conservaran obras de Cosme en La Rioja y el País Vasco. Sin embargo, el propio Banda reconocía después que era más probable que esas imágenes se hubieran realizados en Madrid entre 1781 y 1784, así que no conocemos obras realizadas por Cosme antes de $1773^{7}$.

Por lo tanto, podemos concluir que Cosme Velázquez procedía de una familia modesta, agricultores por ambas partes de su familia, que su padre, además, era administrador de las propiedades de una congregación religiosa y que se casó, ya con más de 40 años, con una joven que procedía de una familia pobre y con un bajo nivel cultural.

\footnotetext{
5 AHPLR, Catastro de Ensenada, Logroño, Memoriales de seglares, vol. 402, fol. 371 r. Aunque Francisco Merino parece un nombre bastante común, parece bastante seguro que éste era el abuelo de Cosme Velázquez. En el Catastro solo se cita a otro Francisco Merino, que no tenía hijas sino solo tres hijos varones y un Lucas Francisco Merino que tenía 25 años en el momento de realizarse el Catastro, por lo que no parece probable que tuviera una hija de la edad de Isabel Merino (AHPLR, Catastro de Ensenada, Logroño, Memoriales de seglares, vol. 402, fol. 440 r. y vol. 404, fol. 24 r).

${ }^{6}$ ARABASF, Libros de matrícula (1752-1815), leg. 3-300, fol. 18 r.

7 BANDA Y VARGAS, Antonio de la, “Evocación del escultor Cosme Velázquez...”, pp. 20-21.
} 
Sin embargo, toda esta información no aclara qué pudo motiva a Cosme a formarse como artista ni qué le decidió a trasladarse a Madrid para estudiar en la Real Academia de San Fernando. Así que queda abierta la posibilidad de una formación previa con un maestro local a la espera de nueva documentación que la confirme.

\section{LOS ESTUDIOS EN LA REAL ACADEMIA DE BELLAS ARTES DE SAN FERNANDO}

El 15 de octubre de 1773, Cosme Velázquez ingresó como alumno en la Real Academia de Bellas Artes de San Fernando en Madrid, a los 18 años de edad ${ }^{8}$. La Real Academia de San Fernando, creada poco más de 20 años antes, ofrecía a sus alumnos una formación teórica, basada en la enseñanza del dibujo y en la copia de esculturas de la antigüedad. Cosme completaba esa formación trabajando como aprendiz en el taller de los escultores Roberto y Pedro Michel ${ }^{9}$.

Los Michel eran dos hermanos escultores, formados en Francia, donde se habían trasladado para trabajar en las obras del Palacio Real. De los dos, el que más destacó fue Roberto, que llegó a ser uno de los escultores más prestigiosos de la Corte española a mediados del siglo XVIII. Michel mantuvo un estilo característico que asumía la serenidad y armonía del estilo academicista pero sin perder la gracia del rococó en que se había formado en Francia ${ }^{10}$.

Poco a poco, Cosme Velázquez fue destacando entre los alumnos más aventajados de la Real Academia. Su aprendizaje se puede valorar por los premios que fue obteniendo en esta institución, y lo cierto es que los resultados fueron muy satisfactorios: en los premios mensuales de la Academia, Cosme fue premiado 6 veces en sus 8 años de estudio y en los premios generales fue premiado en las dos ocasiones en que se presentó: como alumno de la Sala de Yeso ganó un segundo premio en 1778 y como alumno del Natural ganó el primer premio en 1781. Podemos desglosar un poco más la información sobre dichos premios.

\footnotetext{
8 ARABASF, Libros de matrícula (1752-1815), leg. 3-300, fol. 18 r. Cfr. PARDO CANALÍS, E., Los registros de matrícula de la Academia de San Fernando de 1752 a 1815. Madrid, Instituto Diego Velázquez, 1967, p. 115.

${ }_{9}$ AGP, Expedientes personales, Exp. 1083/12, leg. 1, fol. 3 r.

10 Sobre Roberto Michel, ver LORENTE ARÉVALO, Carmen, "Nuevas aportaciones a la biografía del escultor Roberto Michel", Anales de bistoria del arte, 5 (1995), pp. 225-235, disponible en http://revistas.ucm.es/index.php/ANHA/article/viewFile/ANHA9595110225A/31710 (consultado a 11/02/2015); MELENDRERAS GIMENO, José Luis, "La obra de Roberto Michel, Escultor de Cámara del Rey Carlos III", Reales sitios, 90 (1986), pp. 37-44; TÁRRAGA, María Luisa, "Los estucos de Roberto Michel para el Palacio de El Pardo", Archivo español de arte, LXII, 247 (1989), pp. 315-329, disponible en http://digital.csic.es/bitstream/10261/17048/1/20090918094026855.pdf (consultado a 11/02/2015).
} 
Las ayudas de costa o premios mensuales que acabamos de citar eran becas económicas que se otorgaban a los alumnos de cada una de las salas y especialidades de la Academia atendiendo al mérito de una obra presentada por ellos cada mes. Cosme aseguraba en dos memoriales fechados en 1792 y 1816 haber conseguido 6 ayudas de costa: 2 en 1774,1 en 1775,1 en 1777 y 2 en $1780^{11}$. Sin embargo, no parece que su memoria hubiera retenido bien las fechas, porque la información que consta en los libros de Actas de la Real Academia de San Fernando es otra bien distinta. Cosme no aparece entre los premiados en 1774 ni 1775, sino que las dos becas que recibió fueron en 1776: una en mayo y otra en julio. En 1777 sí que consta que ganara una ayuda de costa, en el mes de febrero. Además, fue en esa ocasión cuando se le concedió el pase a la sala del yeso. También consta un premio que él no cita en marzo de 1779. Y, frente a las dos ayudas que él cita en 1780, en realidad una la ganó en mayo de 1780 y la otra en enero de $1781^{12}$.

A esto hay que añadir que en otras ocasiones obtuvo varios votos pero no logró hacerse con la ayuda de costa: en abril de 1776, en diciembre de 1776, en marzo de 1778, en enero de 1779 y en abril y noviembre de $1780^{13}$. Con lo cual, independientemente de las fechas concretas, el hecho de resultar premiado en tantas ocasiones deja claro su prestigio como buen estudiante.

En cuanto a los premios generales, se organizaban cada 3 años a final del curso y concedían 3 premios a cada una de las Salas de cada especialidad (arquitectura, escultura y pintura). El premio era una medalla de bronce, plata u oro según el premio conseguido. Cosme no se presentó en los premios de 1775, ya que llevaba poco más de un año en la Academia. En 1778 se presentó a los premios de la segunda clase, como alumno de la Sala del Yeso, teniendo que realizar dos obras: una de pensado, con un tiempo de 6 meses, con el tema El rey moro de Granada y San Fernando en el cerco de Jaén y una de repente, en apenas una tarde, con el tema Agar en el desierto, con su bijo Ismael moribundo, y el Ángel que le señala la fuente de agua para remediar su sed. Cosme obtuvo el segundo premio en su categoría ${ }^{14}$.

En los siguientes premios, en 1781, Velázquez volvió a presentarse, esta vez en la primera clase, como alumno de la Sala del Natural. En esta ocasión, el tema de pensado fue Alegoría del nacimiento del infante Carlos Eusebio y el tema de repente fue Judit que, habiendo cortado la cabeza de Holofernes, la alarga a una sierva que la recibe en un saco. Cosme logró el primer premio de la primera clase, el mayor galardón que se podía obtener en la Real Academia ${ }^{15}$.

11 ARABASF, Escultores, leg. 173-1/5, s/f. y AGP, Expedientes personales, Exp. 1083/12, leg. 1, fol. 3 r.
${ }^{12}$ ARABASF, Actas, $3-84$ (1776-1785), fols. 20 v., 30 v., 49 r., 122 r., 151 v. y 167 r.
${ }^{13}$ Ibidem, fols. 17 r., 45 v., 75 v., 116 v., 150 r. y 164 r.
${ }^{14}$ Ibídem, fol. 88 v.-94 r. Cfr. ARABASF, Escultores, leg. $173-1 / 5$, s/f.
${ }^{15}$ ARABASF, leg. 3/84, Actas (1776-1785), fol. 184 v.-187 r. Cfr. ARABASF, Escultores, leg. 173-1/5, s/f. 


\begin{tabular}{|l|l|l|}
\hline Fecha & Convocatoria & Premio conseguido \\
\hline Abril 1776 & Premios mensuales & Ayuda de costa \\
\hline Mayo 1776 & Premios mensuales & Ayuda de costa \\
\hline Julio 1776 & Premios mensuales & Votado para ayuda de costa \\
\hline Diciembre 1776 & Premios mensuales & Ayuda de costa + pase Sala yeso \\
\hline Febrero 1777 & Premios mensuales & Votado para ayuda de costa \\
\hline Marzo 1778 & Premios mensuales & Segundo premio de la segunda clase \\
\hline Julio 1778 & Premios generales & Votado para ayuda de costa \\
\hline Enero 1779 & Premios mensuales & Ayuda de costa \\
\hline Marzo 1779 & Premios mensuales & Votado para ayuda de costa \\
\hline Abril 1780 & Premios mensuales & Ayuda de costa \\
\hline Mayo 1780 & Premios mensuales & Votado para ayuda de costa \\
\hline Noviembre 1780 & Premios mensuales & Ayuda de costa \\
\hline Enero 1781 & Premios mensuales & Primer premio de la primera clase \\
\hline Julio 1781 & Premios generales &
\end{tabular}

Gráfico 2. Premios obtenidos por Cosme Velázquez en la Real Academia de Bellas Artes de Madrid

\section{MATRIMONIO Y FAMILIA DE COSME VELÁZQUEZ}

Por esas mismas fechas, en torno a 1780 o 1781, Cosme Velázquez contrajo matrimonio con Claudia Martín ${ }^{16}$. Antonio de la Banda indicaba en sus artículos que el matrimonio habría tenido lugar en Cádiz, cuando Cosme se encontraba ya instalado en esta localidad ${ }^{17}$. En realidad, Cosme y Claudia contrajeron matrimonio en la parroquia de San Ginés, en Madrid.

Claudia Martín era natural de la localidad toledana de Casarrubios del Monte y era hija de Tomás Martín y de Josefa Hernández. No sabemos mucho sobre ella, salvo que su familia parecía ser algo más acomodada que la de Cosme, a juzgar por los bienes que aportó al matrimonio. Aun así, este desahogo económico no se correspondía con una buena formación cultural, porque Claudia no sabía leer ni escribir. Cosme, por su parte, aunque con una mayor educación y una prometedora carrera como escultor se encontraba en una situación económicamente más precaria, ya que al parecer no pudo aportar nada al matrimonio $^{18}$. Y eso a pesar de su trabajo en el taller de los Michel y de su esfuerzo por conseguir la ayuda económica de los premios mensuales.

\footnotetext{
16 AHPC, Cádiz, Protocolos notariales, leg. 5400, fol. 93 v. La información sobre su vida familiar está recogida en los tres testamentos otorgados por Cosme Velázquez: en 1800, en 1816 y en 1837. En el primero indica que hacía como 20 años que había contraído matrimonio y en el segundo que hacía como 35 años, lo cual nos da como fechas de matrimonio los años 1780-1781 (AHPC, Cádiz, Protocolos notariales, leg. 412, fol. 565-568; AHPC, Cádiz, Protocolos notariales, leg. 5400, fol. 92 r.-95 r.; AHPC, Cádiz, Protocolos notariales, leg. 483 , fol. 585 r.-586 v.)

17 BANDA Y VARGAS, Antonio de la, “Evocación del escultor Cosme Velázquez...”, p. 21.

${ }^{18} \mathrm{La}$ información sobre el matrimonio de Cosme procede fundamentalmente de AHPC, Cádiz, Protocolos notariales, leg. 5400, fol. 93 v.-95 r.
} 
Cosme y Claudia tuvieron ocho hijos, aunque cuatro murieron siendo niños y otro más, Tomás Genaro, falleció a los 24 años de edad, quedándoles por tanto tres hijos: Manuel (nacido hacia 1785), Francisco Javier (nacido hacia 1790), y María Teresa (nacida hacia 1794) ${ }^{19}$.

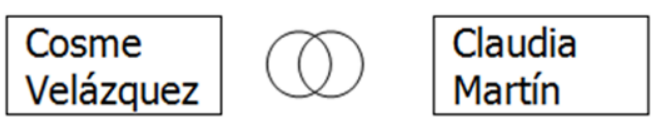

\begin{tabular}{|c|c|c|c|c|c|c|c|}
\hline $\begin{array}{l}\text { Tomás } \\
\text { Genaro } \\
\text { Velázquez }\end{array}$ & $\begin{array}{l}\text { Manuel } \\
\text { Velázquez }\end{array}$ & $\begin{array}{l}\text { Francisco } \\
\text { Javier } \\
\text { Velázquez }\end{array}$ & $\begin{array}{l}\text { María } \\
\text { Teresa } \\
\text { Velázquez }\end{array}$ & \multirow[t]{2}{*}{ (D) } & $\begin{array}{l}\text { Juan } \\
\text { Bautista } \\
\text { Mombello }\end{array}$ & & \multirow[t]{2}{*}{\begin{tabular}{|l|} 
Cosme \\
Mombello \\
Velázquez
\end{tabular}} \\
\hline & & & & & $\begin{array}{l}\text { Antonio } \\
\text { Márquez }\end{array}$ & & \\
\hline
\end{tabular}

Gráfico 3. Árbol genealógico de los descendientes de Cosme Velázquez

De los tres, solo Francisco Javier siguió la tradición artística de su padre, pero no como escultor sino como arquitecto, llegando a ser Arquitecto Mayor de Jerez de la Frontera. Su título de arquitecto proviene de la Real Academia de Bellas Artes de San Carlos de Méjico, donde su padre le envió en 1811 debido a que las Academias de la península estaban cerradas por la guerra contra los franceses ${ }^{20}$. Manuel, por su parte, fue Teniente Coronel del Ejército ${ }^{21}$. María Teresa, sin embargo, no recibió ninguna educación: ya en 1816, sus padres reconocían que habían gastado mucho dinero en la educación de sus hijos varones y nada en la educación de María Teresa, una desigualdad que intentaron paliar concediéndole una mejora en el testamento ${ }^{22}$. Aunque era frecuente que la educación femenina no fuera tan importante como la masculina, sí que existen casos contemporáneos en los que las mujeres van adquiriendo cada vez más una educación. Sin embargo, si Claudia no había aprendido a leer ni escribir y Cosme procedía de una familia donde también estaba presente el analfabetismo, es posible que no consideraran tan importante el acceso a la educación femenina.

\footnotetext{
${ }^{19}$ AHPC, Cádiz, Protocolos notariales, leg. 5400, fol. 93 v.-94 r. Cuando se otorgó este testamento en 1816, Manuel tenía más de 30 años, Francisco Javier 26 y María Teresa 22.

${ }^{20}$ FUENTES ROJAS, Elizabeth, et al., La Academia de San Carlos y los constructores del Neoclásico: primer catálogo de dibujo arquitectónico, 1779-1843. Universidad Nacional Autónoma de México, Escuela Nacional de Artes Plásticas, 2002, pp. 339-340.

${ }^{21}$ AHPC, Cádiz, Protocolos notariales, leg. 5400, fol. 93 v.-94 r. Cfr. BANDA Y VARGAS, Antonio de la, "Evocación del escultor Cosme Velázquez...", p. 21.

22 "Atendiendo a los muchos gastos que se nos ha originado en la educación de nuestros dos hijos varones y porque particularmente para darles carrera se nos han causado y los ningunos con la dicha nuestra hija d[oñ]a María Teresa..." (AHPC, Cádiz, Protocolos notariales, leg. 5400, fol. 94 v.)
} 
Sí que sabemos que María Teresa contrajo matrimonio con Juan Bautista Mombello, con quien tuvo un hijo, Cosme Mombello Velázquez (nacido hacia 1823), y tras la muerte de su esposo, casó en segundas nupcias con Antonio Márquez, "profesor de farmacia" en Cádiz ${ }^{23}$.

El matrimonio entre Cosme y Claudia duró 37 años, hasta la muerte de Claudia el 11 de diciembre de $1818^{24}$. Cosme, por su parte, sobrevivió a su mujer casi 20 años, hasta que falleció en Cádiz el 4 de noviembre de 1837, a los 82 años de edad ${ }^{25}$.

\section{LA LLEGADA A CÁdiz Y EL APOYO DE TORCUATO CAYÓN Y TORCUATO BENJUMEDA}

Tras su boda, Cosme continuó, según él mismo declara en el memorial que redactó en $1792^{26}$, con sus estudios en la Real Academia durante tres años más, años en los que además empezó a colaborar con arquitectos como Ventura Rodríguez ${ }^{27}$. Hacia 1784, sin embargo, el obispo de Cádiz, don José Escalzo y Miguel, le pidió que se trasladara a esa ciudad para trabajar en las obras de una nueva iglesia dedicada a San Josée ${ }^{28}$.

Aunque Cosme no dice nada de por qué el obispo Escalzo recurrió a él, la mayor parte de los historiadores coincide en que probablemente la conexión vino a través de Torcuato Cayón, arquitecto muy importante en Cádiz y suegro de Ventura Rodríguez, quien debió de hablarle del joven escultor logroñés. De hecho, Cosme entró a formar parte del círculo artístico de Torcuato Cayón, entablando una fuerte amistad con el ahijado de éste, el arquitecto Torcuato Benjumeda. Benjumeda y Velázquez coincidieron en las obras de la iglesia de san José, al poco de llegar Cosme a Cádiz. Benjumeda había trazado el edificio de la iglesia, Velázquez se encargaría de su decoración escultórica. Esta colaboración artística fue la primera de otras obras en las que Benjumeda trabajaba como arquitecto y Velázquez como escultor: la iglesia de Nuestra Señora del Rosario, el Oratorio de la Santa Cueva, el ayuntamiento de Cádiz o la Cárcel Real, por ejemplo.

Además de esta relación profesional, hay varios sucesos de la vida de Cosme Velázquez en los que también aparecerá como protagonista Torcuato Benjumeda. Así,

\footnotetext{
23 AHPC, Cádiz, Protocolos notariales, leg. 483, fol. 585 v.

24 AHPC, Cádiz, Protocolos notariales, leg. 5400, fol. 92 r., nota al margen.

25 AHPC, Cádiz, Protocolos notariales, leg. 483, fol. 585 r., nota al margen.

26 ARABASF, Escultores, leg. 173-1/5, s/f.

27 PARDO CANALÍS, Enrique, “Cosme Velázquez,...”, p. 49.

28 ARABASF, Escultores, leg. 173-1/5, s/f.
} 
ambos serán profesores en la Escuela de Bellas Artes de Cádiz, creada en $1789^{29}$. Debido a su trabajo en esta escuela, ambos se involucrarán en 1811 en un conflicto contra el secretario de la misma, Tomás Sisto, quien había propuesto una reforma de esta institución. Velázquez y Benjumeda, junto con el Director de Arquitectura Pedro Ángel de Albizu, trataron de frenar la reforma publicando su oposición en la prensa local, lo cual supuso cierto revuelo en la ciudad ${ }^{30}$. La cercanía entre ambos artistas llegaba incluso a la proximidad de sus vivienda: Antonio Orozco indica que ambos artistas eran casi vecinos, ya que según él: “Cosme Velázquez (...) vivía en la plaza de la Cruz Verde n 1, próxima de D. Torcuato Benjumeda, que habitaba la casa no 198 antiguo" ${ }^{\prime 31}$. Y un último detalle es que cuando Cosme otorgue testamento tanto en 1800 como en 1816 nombrará como albaceas suyos a Torcuato y a Juan Benjumeda ${ }^{32}$.

\section{VELÁZQUEZ Y EL CÍRCULO RIOJANO EN CÁDIZ}

Aunque hemos señalado el apoyo de Cayón y Benjumeda como esenciales para explicar el asentamiento definitivo de Cosme en Cádiz, hay otro campo interesante que en este artículo vamos a esbozar quedando a la espera de algún estudio posterior: la relación de Cosme Velázquez con otros riojanos asentados en Cádiz a finales del siglo XVIII.

En estos años, se observa en la ciudad de Cádiz la coincidencia de varios riojanos que tuvieron un papel destacado en la vida económica, religiosa y artística de esa ciudad. Personajes como Sebastián Martínez, gran comerciante nacido en Treguajantes ${ }^{33}$, fray Domingo de Silos Moreno, obispo de Cádiz y oriundo de Cañas ${ }^{34}$, o José de Santa María, marqués de Valdeínigo, quien a pesar de haber nacido en Veracruz era hijo de emigrantes riojanos.

No parece que Cosme hubiera tenido contacto previo con ellos en La Rioja, ya que no coincidieron entre sí y eran de localidades diferentes. Sin embargo, es innegable que, fuera del lugar de nacimiento, los vínculos entre personas de la misma región se fortalecen, facilitando relaciones que tal vez no hubieran existido en el lugar de origen. Un ejemplo

29 Sobre este tema, ver GASCÓN HEREDIA, María Teresa, Estudio bistórico..., así como OROZCO ACUAVIVA, Antonio, Orígenes de la Academia...

${ }^{30}$ Sobre esta polémica, ver GASCÓN HEREDIA, María Teresa, Estudio histórico..., pp. 168-171, BANDA Y

VARGAS, Antonio de la, "Evocación del escultor Cosme Velázquez...”, pp. 19-31.

31 OROZCO ACUAVIVA, Antonio, Orígenes de la Academia..., p. 9.

32 AHPC, Cádiz, Protocolos notariales, leg. 412, fol. 565-568 y leg. 5400, fol. 92 r.-95 r.

33 GIL-DÍEZ USANDIZAGA, Ignacio, "Sebastián Martínez, el amigo de Goya", Brocar: Cuadernos de

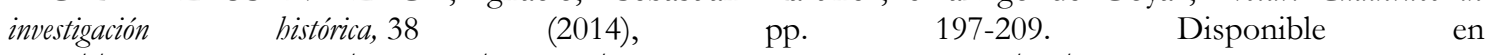
http://dialnet.unirioja.es/descarga/articulo/4903767.pdf (consultado a 11/02/2015)

34 MERINO URRUTIA, José Juan Bautista, "El riojano fray Domingo de Silos Moreno, obispo de Cádiz", Berceo, 84 (1973), pp. 121-126. 
nos lo proporciona el propio Cosme, de quien conservamos una carta dirigida a Martín Fernández de Navarrete, secretario de la Real Academia, en la que se refiere al Marqués de Monesterio como "paysano nuestro", ya que los tres eran riojanos ${ }^{35}$. Es decir, que el nacimiento en la misma región se convierte en un vínculo que une a un noble como el Marqués de Monesterio, un militar e intelectual como Fernández de Navarrete y un artista de origen humilde como Cosme Velázquez.

También en Cádiz Cosme tuvo relación con los ilustres riojanos que acabamos de citar. Para el Marqués de Valdeínigo, por ejemplo, realizó trabajos escultóricos tanto en los retablos de la iglesia de Nuestra Señora del Rosario, como en el oratorio de la Santa Cueva, obras ambas sufragadas por el Marqués ${ }^{36}$. Y con Sebastián Martínez se relacionó con toda seguridad, ya que existen pruebas documentales del contacto entre ellos: Sebastián Martínez fue nombrado albacea y testamentario de Cosme Velázquez en uno de los testamentos que este redactó. En efecto, en 1800, Cosme y su esposa otorgaban testamento ante el escribano Manuel Sáenz. En él, nombraban albaceas testamentarios y ejecutores de su última voluntad “a d[o]n Sebastián Martínez, d[o]n Ventura Ymaña y d[o]n Pedro Alonso Ocruley [sic]"37. En cambio, aunque posiblemente se conocieran, el trato con fray Domingo de Silos Moreno debió de ser menos intenso, ya que fray Domingo fue designado obispo de Cádiz en 1825, cuando Cosme tenía ya 70 años y apenas realizaba obras escultóricas.

Estos vínculos que hemos señalado indican que Cosme conocía a estos riojanos, y que, en el caso de Sebastián Martínez, parece existir una relación de confianza suficiente para solicitarle una responsabilidad como es ser albacea testamentario. Además, estos contactos resultaron muy beneficiosos para su actividad como artista, ya que el marqués de Valdeíñigo le encargó la ejecución de obras y el contacto con Sebastián Martínez tal vez le permitió acceder a la biblioteca y colección artística de éste, así como ponerle en contacto con los artistas a los que Martínez conocía, algunos tan destacados como Francisco de Goya.

Sin embargo, no parece que el prestigio de Cosme como escultor en la ciudad se deba únicamente al apoyo de este círculo de prestigiosos riojanos, ya que Cosme trataba por igual a otros personajes ilustres de la ciudad que no tenían un origen riojano. Es

\footnotetext{
35 "Por el exmo Sor. Marqués de Monesterio, Paysano nuestro, he sabido que S.M. se ha servido honrrarme con el título de Escultor de Cámara honorario...” (PARDO CANALÍS, Enrique, “Cosme Velázquez,...”, p. 48).

36 ALONSO DE LA SIERRA FERNÁNDEZ, Juan y Lorenzo, "Trabajos en yeso de Cosme Velázquez...", pp. 76-86.

${ }_{37}$ AHPC, Cádiz, Protocolos notariales, leg. 412, fol, 565 r.-568 v.
} 
significativo, por ejemplo, que, como albacea de su testamento, además de Martínez, aparezca también el famoso comerciante y anticuario Pedro Alonso O’Crowley ${ }^{38}$.

En cualquier caso, cuando Cosme llegó a Cádiz para trabajar en la iglesia de San José, encontró una ciudad muy interesada en el arte academicista y cortesano, con posibilidades económicas para sufragar un gran número de obras, y donde pronto encontró el apoyo de amigos como Cayón y Benjumeda y de paisanos dispuestos a convertirse en mecenas y patrocinadores. Estas buenas expectativas explican que el traslado de Cosme a Cádiz acabara por ser definitivo.

\section{ACADÉMICO EN LAS ACADEMIAS DE MADRID Y MÉXICO Y ESCULTOR DE CÁMARA HONORARIO}

En 1795, siendo ya profesor de la Escuela de Nobles Artes de Cádiz, Cosme obtuvo el nombramiento como Académico de Mérito de la Real Academia de San Fernando ${ }^{39}$.

Este nombramiento ha sido ya analizado Pardo Canalís, quien recogió en su artículo la documentación existente sobre este nombramiento en el Archivo de la Real Academia de San Fernando ${ }^{40}$. Podemos añadir que el relieve que presentó para solicitar el título, que representaba a Artabaces, rey de Armenia, conducido en triunfo por Marco Antonio ante Cleopatra, ha sido ampliamente citado en la bibliografía sobre la escultura de la Real Academia de San Fernando ${ }^{41}$.

También podemos indicar que este nombramiento llevó a que la Real Academia solicitara ocasionalmente la ayuda de Cosme para diversas labores. Así por ejemplo, durante el trienio liberal, se le pidió a Cosme que revisara una lápida en homenaje de las Cortes de Cádiz, realizada por Juan Daura y Pedro de la Puente, como consecuencia de un encargo de la Real Academia de San Fernando fechado el 12 de agosto de 1821. Años más tarde, en 1836, se creó en Cádiz una Comisión Provincial del Inventario Artístico cuyo fin era inventariar los bienes afectados por la desamortización de Mendizábal, Comisión de la que Cosme fue nombrado miembro ${ }^{42}$. Además cuando, como hemos comentado, hubo un

\footnotetext{
38 Sobre Pedro Alonso O'Crowley, ver BERNABEU ALBERT, Salvador, "Pedro Alonso de O'Crouley y O’Donnell (1740-1817) y el descubrimiento ilustrado de México", Digital CSIC (2010). Disponible en http://digital.csic.es/bitstream/10261/79277/1/Pedro\%20Alonso $\% 20 \mathrm{de} \% 20$ O'Crouley. $\% 20 B e r n a b \% C 3 \%$ A9u,\%20Salvador.pdf (consultado a 11/02/2015).

39 ARABASF, Escultores, leg. 173-1/5, s.f. Cfr. AGP, Expedientes personales, Exp. 1083/12, leg. 1, fol. 1 r.v. y fol. 3 r. y v.

40 PARDO CANALÍS, Enrique, “Cosme Velázquez,...”, p. 43-50.

41 AZCUE BREA, Leticia, La escultura en la Real Academia ..., pp. 262-263.

${ }^{42} \mathrm{La}$ relación de las obras y méritos de Cosme se encuentra en ARABASF, Escultores, leg. 173-1/5, s/f. y AGP, Expedientes personales, Exp. 1083/12, leg. 1, fol. 3 r.
} 
enfrentamiento entre Velázquez, Benjumeda y Albizu contra Tomás Sisto, secretario de la Escuela de Nobles Artes de Cádiz, Cosme hizo valer su título de Académico de Mérito para defender sus prerrogativas como escultor ${ }^{43}$.

Quince años después, en 1810, Cosme obtuvo otro nombramiento como Académico de Mérito, en este caso por la Real Academia de Bellas Artes de Méjico en 1810. Cosme no aporta mucha información sobre este nombramiento, limitándose a decir en un memorial de 1817 que "en el año de 810 lo recibió por su académico de mérito la R[ea]l Academia de S[a]n Carlos de México por obra presentada para d[ic]ho fin" ${ }^{44}$. No sabemos de qué obra se trató, ni tampoco qué motivó a Cosme a solicitar este nombramiento. Y se trata de un aspecto que apenas ha sido tratado en otros artículos sobre este escultor.

Podemos, sin embargo aventurar una hipótesis: es posible que Cosme solicitara este título por mediación de Manuel Tolsá. Tolsá era un arquitecto de origen valenciano que fue nombrado director de Real Academia de Bellas Artes de Méjico. En su viaje a este país, Tolsá se detuvo un tiempo en Cádiz, donde incluso dio traza para un retablo de la iglesia parroquial de Nuestra Señora del Rosario, en la que Cosme estaba realizando la decoración escultórica ${ }^{45}$. De ahí debió nacer el contacto de Velázquez con Tolsá, quien parece haber sido el intermediario más lógico para el nombramiento de Velázquez como académico de mérito en Méjico. De hecho, cuando su hijo Francisco Javier vaya a estudiar a Méjico, realizará sus estudios bajo la dirección de Manuel Tolsá ${ }^{46}$.

Por último, en noviembre de 1816, ya con 61 años de edad, Cosme obtuvo el nombramiento de Escultor de Cámara Honorario del Rey ${ }^{47}$. Este título suponía un prestigio para los artistas que lo obtenían, además de un sueldo extraordinario y la posibilidad de realizar encargos para el Rey, posibilidad que probablemente a Cosme le interesaba menos porque implicaba la necesidad de trasladarse a Madrid o a cualquiera de los Sitios Reales.

\footnotetext{
${ }^{43}$ GASCÓN HEREDIA, María Teresa, Estudio bistórico..., pp. 168-171.

${ }^{44}$ AGP, Expedientes personales, Exp. 1083/12, leg. 1, fol. 3 r. Cfr. BÁEZ MACÍAS, Eduardo, Guía del archivo de la Antigua Academia de San Carlos, 1781-1910. Ciudad de México, Unam, 2003, p. 26.

45 ALONSO DE LA SIERRA FERNÁNDEZ, Lorenzo, El retablo neoclásico en Cádiz, Cádiz, Diputación Provincial de Cádiz, 1989, p. 39.

${ }^{46}$ FUENTES ROJAS, Elizabeth, et al., La Academia de San Carlos..., p. 339.

47 AGP, Expedientes personales, exp. 1083/12, leg. 1, fol. 1 r.-3 r. Cfr. PARDO CANALÍS, Enrique, "Cosme Velázquez,...”, pp. 42-49.
} 


\section{SOCIO DE MÉRITO DE LA REAL SOCIEDAD DE SANLÚCAR DE BARRAMEDA}

Un poco antes, en 1807 había recibido otro nombramiento honorífico, aunque menos vinculado con el mundo del arte: el nombramiento como socio de mérito de la Real Sociedad de Sanlúcar de Barrameda en 1807. Este nombramiento lo obtuvo por realizar un estudio sobre las clases de vides de aquel territorio por encargo de la Corte ${ }^{48}$.

Hasta ahora no se había prestado mucha atención a este suceso de la vida de Cosme, a pesar de que él hace referencia a este nombramiento en el memorial que escribió solicitando su nombramiento como Escultor de Cámara Honorario del Rey. Sin embargo, llama la atención porque es el único de los nombramientos que no tiene relación con el mundo del arte. Además, no hemos localizado información sobre en qué consistió el trabajo, aunque sabemos que, efectivamente, en 1807 la Real Sociedad de Sanlúcar de Barrameda comisionó a diversos especialistas para realizar estudios sobre las viñas del territorio, entre ellos naturalistas como Simón de Rojas Clemente y Rubio y Esteban Boutelou ${ }^{49}$.

No hemos encontrado constancia del trabajo de Cosme, oscurecido por el de estos naturalistas más prestigiosos. Aun así, resulta interesante un encargo de este tipo, por cuanto demuestra que Cosme debió de haber adquirido de su familia conocimientos agrícolas, ya que ésta era la profesión que desempeñaban tanto su padre como su abuelo. Por lo tanto, este título está relacionado con esos años de juventud riojanos de los que tan poco se sabía hasta ahora.

El traslado de Cosme a Sanlúcar de Barrameda para este trabajo, además, pudo ser el origen de un encargo que se le ha atribuido: la escultura de la talla de la Divina Pastora para el convento de capuchinos de esta localidad. Esta imagen, que representa a María con un pellico de piel de oveja y dos corderos a sus pies, uno de los cuales está acariciando, mezcla el encanto y gracia de la tradición escultórica andaluza con una perfección técnica y una armonía que revelan la influencia académica. Y es esa influencia académica la que llevó en 1949 al Padre Ardales a atribuir esta obra a Cosme Velázquez, por ser el escultor académico más prestigioso de esta región, igual que le atribuye, por similitudes estéticas otra Divina Pastora, conservada en el convento de Jerez de la Frontera. Fernando Cruz

\footnotetext{
48 AGP, Expedientes personales, Exp. 1083/12, leg. 1, fol. 3 r.

${ }^{49}$ BOUTELOU, Esteban, Memoria sobre el cultivo de la vid en Sanlícar de Barrameda y Xerez de la Frontera. Madrid, 1807 y CLEMENTE, Simón de Rojas et al., Ensayo sobre las variedades de la vid común que vegetan en Andalucía con un indice etimológico y tres listas de plantas en que se caracterizan varias especies nuevas, Madrid, Imprenta de Villalpando, 1807.
} 
Isidoro recoge la atribución de la talla sanluqueña, aunque en su análisis estilístico indica como otro posible autor al escultor Cristóbal Ramos ${ }^{50}$. Fernando Cruz Isidoro también atribuye a Velázquez otra imagen, la Virgen de las Angustias, también en Sanlúcar de Barrameda, que fue precisamente realizada en $1807^{51}$.

\section{LA LABOR ESCULTÓRICA DE COSME VELÁZQUEZ}

Cosme Velázquez realizó un gran número de obras, que en general, han sido ampliamente estudiadas por historiadores: el artículo más completo sigue siendo el de Banda y Vargas ${ }^{52}$, pero también Juan y Lorenzo Alonso de la Sierra han estudiado sus obras en la Santa Cueva $^{53}$, Álvaro Recio Mir el tabernáculo de la iglesia prioral del Puerto de Santa María (un espacio en el que trabajó a la vez que su hijo Francisco Javier ${ }^{54}$, Sancho de Sopranis la imagen de Carlos III para La Habana ${ }^{55}$, y Leticia Azcue las obras conservadas en la Real Academia de San Fernando ${ }^{56}$.

En cambio, sigue habiendo obras realizadas por Cosme y que apenas se conocen, sobre todo las citadas por él en un memorial citado en 1792 $2^{57}$ : "para Oyón, en Álava, una Concepción; para Navarrete en Rioxa una Virgen del Rosario del natural y un S[a]n Josef para Santander, una ymagen del Rosario para Buenos Aires, una Concepción para Canarias, un Santo Tomás y otras efijies que omito por no molestar a v[uestra] e[xcelencia]".

Antonio de la Banda supone, y estamos de acuerdo con él, que las imágenes de Álava, La Rioja y Santander debió de realizarlas en Madrid, en los años que mediaron entre el primer premio en la Real Academia y el traslado a Cádiz (1781-1784). En cambio, las imágenes de Buenos Aires, Canarias y La Habana serían ya realizadas en Cádiz, y probablemente los encargos fueron facilitados por la apertura de esta ciudad al Atlántico y las colonias de ultramar ${ }^{58}$.

\footnotetext{
${ }^{50}$ CRUZ ISIDORO, Fernando, El Convento Sanluqueño de Capuchinos. Arte e Historia de una Fundación Gurmana. Sanlúcar de Barrameda, Asociación Sanluqueña de Encuentros con la Historia y el Arte (A.S.E.H.A.), 2002, pp. 131-136.

${ }_{51}$ Cfr. CRUZ ISIDORO, Fernando, La Real Hermandad de las Angustias: Estudio histórico del Patrimonio Artístico. Sanlúcar de Barrameda, Hermandad de las Angustias, 2005.

${ }^{52}$ BANDA Y VARGAS, Antonio de la, “Evocación del escultor Cosme Velázquez...”, pp. 19-31.

53 ALONSO DE LA SIERRA FERNÁNDEZ, Juan y Lorenzo, "Trabajos en yeso de Cosme Velázquez...”, pp. 76-86.

${ }^{54}$ RECIO MIR, Álvaro, "La transformación neoclásica de la iglesia prioral del Puerto de Santa María (Cádiz): tabernáculo, presbiterio y coro", Laboratorio de Arte: Revista del Departamento de Historia del Arte, 19 (2006), pp. 303-327.

55 SANCHO DE SOPRANIS, Hipólito, “Algunas noticias...”.

56 AZCUE BREA, Leticia, La escultura en la Real Academia... p. 262.

${ }^{57}$ ARABASF, Escultores, leg. 173-1/5, s/f.

58 BANDA Y VARGAS, Antonio de la, "Evocación del escultor Cosme Velázquez...", p. 27.
} 
En este artículo podemos ofrecer información sobre dos de ellas: la imagen de la Concepción para Oyón y la Virgen del Rosario para Navarrete.

La imagen de la Concepción que Velázquez realizó ha sido situada, según los autores que trataban sobre él, en diferentes localidades: Serrano Fatigati hablaba de la localidad de Oyar ${ }^{59}$ y Banda y Vargas de la de Oya ${ }^{60}$. Sin embargo, el nombre correcto de la localidad es Oyón, que efectivamente, es una localidad alavesa situada muy cerca de Logroño, la ciudad natal de Cosme. En 1967, esa imagen todavía se conservaba en la iglesia, ya que en el Catálogo monumental publicado ese año se citaba, en la sacristía de la iglesia parroquial, una “Inmaculada Concepción. Rococó. Fina. Procede del ostensorio retirado en la actualidad"61. Sin embargo, la visita in situ a la iglesia de la localidad reveló que la imagen ya no se guardaba en esa sacristía y se desconocía su paradero actual.

En cuanto a la imagen de la Virgen del Rosario, sí que ha podido ser identificada, teniendo por lo tanto una nueva obra para añadir al catálogo de Cosme Velázquez.

\section{ATRIBUCIÓN DE UNA NUEVA ESCULTURA: LA VIRGEN DEL ROSARIO DE NAVARRETE}

La imagen de la Virgen del Rosario que Cosme cita fue realizada en torno a 1782 para el retablo de Nuestra Señora del Rosario situado en la iglesia parroquial de Nuestra Señora de la Asunción de Navarrete, una localidad riojana situada a 11 kilómetros de Logroño.

\footnotetext{
${ }^{59}$ SERRANO FATIGATI, E., Escultura en Madrid... op.cit., p. 202.

${ }^{60}$ BANDA Y VARGAS, Antonio de la, "Evocación del escultor Cosme Velázquez...”, p. 27.

${ }^{61}$ ENCISO VIANA, Emilio-CANTERA ORIBE, Julián, Catálogo Monumental. Diócesis de Vitoria. Tomo I. Rioja Alavesa. Vitoria, 1967, p. 136.
} 


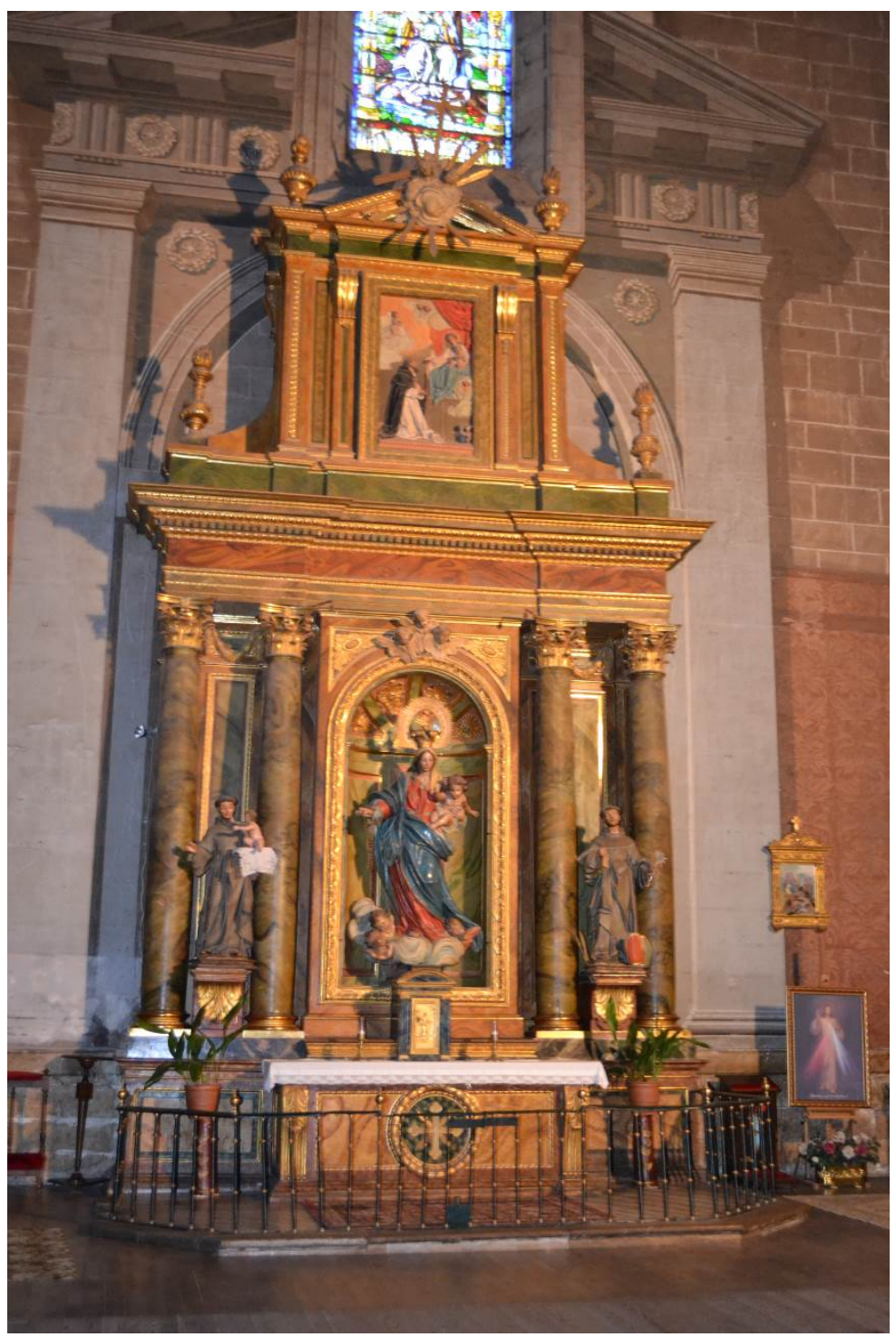

Imagen 1. Retablo de Nuestra Señora del Rosario. Iglesia parroquial de Navarrete (La Rioja)

Este retablo se encuentra en la capilla del transepto del lado evangelio de la iglesia. Es un pequeño retablo neoclásico construido por los escultores Manuel de Ágreda Ilarduy y Francisco de Sabando y que hace pareja con otro retablo gemelo situado en la capilla del lado epístola. Estos dos retablos han sido estudiados por varios especialistas del arte riojano, ya que son dos de los primeros retablos neoclásicos de la región ${ }^{62}$. Sin embargo, hasta ahora no se había atribuido a Cosme la autoría de la imagen de la Virgen del Rosario.

Los retablos fueron construidos en torno a 1782, por lo que su cronología coincide con la época en la que Cosme realizaría su imagen.

62 AHPLR, Protocolos notariales, Navarrete, Manuel Martín de Velasco, leg. 1459, año 1782, 113 r.- 129 r. Sobre estos retablos, ver GUTIÉRREZ PASTOR, Ismael, "Unos retablos de la parroquia de la Asunción de Navarrete", en Segundo coloquio sobre Historia de La Rioja. Logroño, Colegio Universitario, 1986, tomo III, pp. 297-310 y RAMÍREZ MARTÍNEZ, José Manuel, La iglesia de Navarrete. Logroño, Nueva Rioja, 1988, pp. 3639. 
Se sabe además que, aunque el retablo fue realizado por dos arquitectos de la zona, la imagen había sido realizada en Madrid. Era algo habitual en estos momentos encargar tallas devocionales en Madrid, ya que se adecuaban al estilo cortesano que imperaba en esos momentos. En este caso, contamos con el testimonio de Gaspar de Jovellanos, quien visitó Navarrete en 1795 y pudo contemplar estos retablos poco después de su ejecución, indicando en su diario que le habían parecido "dos lindos retablos en el crucero, modernos de buena forma, bien marmoleados, con mediana escultura, aunque venida de Madrid" ${ }^{63}$.

Otro punto que apoya la autoría de Cosme es que este escultor tenía contacto con los artistas que realizaron los retablos. En efecto, uno de los arquitectos, Manuel de Ágreda Ilarduy, era padre de Esteban de Ágreda, un joven estudiante de la Real Academia que en esos momentos estaba colaborando con su padre en la decoración escultórica de esos retablos $^{64}$. Y Esteban conocía sin duda a Cosme Velázquez: ambos eran logroñeses, tenían una edad muy similar (Cosme tenía 4 años más que Esteban), habían estudiado en la Real Academia con sólo un año de diferencia y ambos habían sido aprendices en el taller de Roberto Michel. Por lo tanto, es probable que cuando la iglesia de Navarrete expresó su deseo de encargar a algún escultor de Madrid la realización de la imagen de la Virgen del Rosario, Esteban sugiriera el nombre de Cosme como posible autor para esta imagen: al fin y al cabo, Cosme había ganado el primer premio de la primera clase de escultura en la Real Academia de San Fernando justamente el año anterior.

De hecho, esta teoría tiene otro argumento a su favor, ya que años después veremos otra coincidencia entre ambos que casi puede interpretarse como una devolución del favor de Velázquez a Ágreda. A principios del siglo XIX, Esteban de Ágreda realizó una escultura que representaba a San José para la parroquia de Casarrubios del Monte ${ }^{65}$. Precisamente, Casarrubios era, como hemos indicado, la localidad natal de Claudia Martín, la esposa de Cosme Velázquez. Así que existe la posibilidad de que la parroquia contactara con Cosme por ser un escultor académico ligado a la localidad y éste, que tal vez por esos momentos estaba inmerso en la docencia en la Escuela de Artes de Cádiz, recomendara a Ágreda para hacer la imagen en su lugar. Por el momento, esta suposición queda como una hipótesis que tal vez pueda ser confirmada o desmentida por nuevos hallazgos documentales.

\footnotetext{
${ }^{63}$ JOVELLANOS, Gaspar Melchor de, "Diarios", en Obras completas. Oviedo, Instituto Feijoo-Ayuntamiento de Gijón, 1999, tomo VII, p. 202.

${ }^{64}$ FERREIRA FERNÁNDEZ, Myriam, Los Ágreda: la evolución de la escultura del taller barroco a la Academia neoclásica, Logroño, Instituto de Estudios Riojanos, 2014, pp. 299-301.

${ }_{65}$ ARABASF, leg. 173-2/5, Escultores (1800-1818), s/f, 27 de julio de 1814.
} 
Por último, otro detalle que avalaría la atribución de esta escultura a Cosme sería que esta figura muestra una gran influencia del estilo escultórico de Roberto Michel. Ya lo señalaba Ismael Gutiérrez Pastor en el artículo que dedicó en 1986 a estos retablos, donde indicaba: "el plegado de paños en largos dobleces finos y quebrados es el característico de la escultura de Michel" y precisaba: "la imagen de la Virgen del Rosario se inspira directamente en la Virgen del Carmen esculpida en piedra por Roberto Michel para la fachada de San Hermenegildo de Madrid", hoy en día iglesia de San José ${ }^{66}$.

La coincidencia de las fechas, el hecho de que la figura proceda de Madrid, la relación de Cosme con los artífices del retablo y la influencia de Michel en el modelo iconográfico y en los aspectos técnicos de la figura nos permiten identificar esta figura con la Virgen del Rosario realizada por Cosme Velázquez para la localidad de Navarrete.

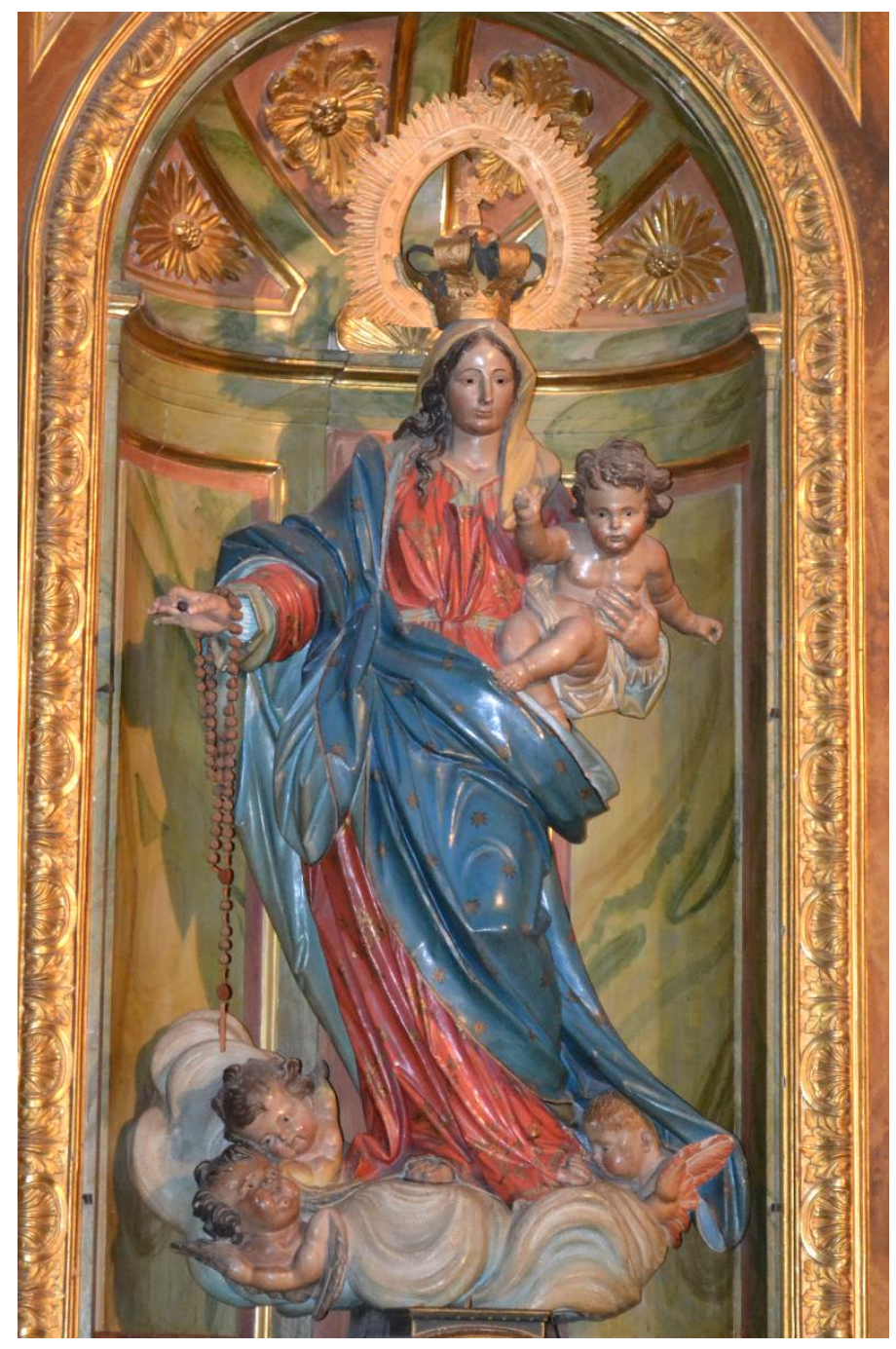

Imagen 2. Virgen del Rosario. Iglesia parroquial de Navarrete (La Rioja)

${ }^{66}$ GUTIÉRREZ PASTOR, Ismael, “Unos retablos...”, p. 304. 
La imagen muestra a la Virgen de pie, apoyada sobre una gloria de nubes por la que asoman tres cabezas de angelitos: dos de ellos mirándose en el lado izquierdo y otro en solitario en el lado derecho. Los dos de la izquierda tienen cabellos rizados, el de la derecha es más rubio y tiene el cabello corto. La Virgen tiene el cabello largo y ondulado, que cae en guedejas sobre el hombro derecho. Su rostro es fino, pero serio e inexpresivo. Tiene los ojos pequeños, las cejas delgadas, la nariz recta y la boca pequeña, con mandíbula redondeada y algo retrasada, lo que hace que su rostro parezca débil y poco agraciado. Se cubre la cabeza con un velo color marfil y viste un vestido rojo con rameados dorados, con un cinturón y con las mangas recogidas mostrando la blusa. Las vestiduras tienen abundantes pliegues: un gran pliegue en el centro del cuerpo, que aporta dinamismo a las vestiduras y numerosos pliegues en las mangas y en la parte inferior del vestido, todos ellos agitados y nerviosos. Lleva un manto azul que cubre el hombro y brazo derecho y se enrolla alrededor de la cintura cayendo sobre la pierna izquierda. También este manto forma numerosos pliegues, abullonándose a la altura de la cadera y pegándose a la pierna izquierda, dejando intuir la forma de la rodilla. Su brazo derecho se extiende hacia el espectador, sosteniendo un gran rosario con cuentas de madera, mientras con la mano izquierda sostiene al Niño Jesús, que tiene el cuerpo proyectado hacia delante, hacia los fieles, a los que bendice con su mano derecha.

\section{APORTACIONES DE ESTA NUEVA ATRIBUCIÓN AL ESTILO DE COSME VELÁZQUEZ}

La imagen de la Virgen del Rosario de Navarrete nos permite conocer algo mejor el estilo artístico de Cosme Velázquez, sobre todo en lo que se refiere a sus obras de juventud. En este sentido, vamos a fijarnos en tres características concretas: la huella del aprendizaje con Roberto Michel, la presencia de la doble influencia rococó y clasicista y la maestría en la representación de los niños.

Como indicábamos previamente, la imagen copia el modelo de la Virgen realizada para la portada de la actual iglesia de San José de Madrid por Roberto Michel. Efectivamente, ambas imágenes están de pie, extendiendo el brazo derecho y sosteniendo al Niño Jesús con el brazo izquierdo, cubiertas con un velo que cae por la espalda a la izquierda y pasa sobre el hombro a la derecha y se apoyan en unas nubes dinámicas por las que asoman cabezas de angelitos. También son similares los pliegues del manto, abullonados a la altura de la cadera, y la forma de las mangas, con la túnica recogida en numerosos pliegues y dejando ver la camisa. Asimismo, en ambos casos el manto se pega a la pierna marcando la forma de la rodilla. Solo difieren los pliegues de la túnica, ya que el peculiar pliegue del pecho presente en la imagen de Navarrete, no se aprecia en la escultura de Michel por llevar el escapulario. Y, como ya indicaba Gutiérrez Pastor, ambas imágenes 
coinciden en el tratamiento de los pliegues, sobre todo en la parte inferior de las vestiduras, donde se abren en abanico con pliegues muy menudos y nerviosos.

Sin embargo, la comparación con la Virgen del Carmen realizada por Roberto Michel nos muestra, además de las similitudes ya comentadas, ciertas diferencias. Aunque técnica y estilísticamente ambas imágenes tienen aspectos similares, el estilo de la una y la otra son muy diferentes. La imagen de Michel es una imagen de rostro dulce y cara aniñada, que sonríe suavemente, igual que sonríen abiertamente las imágenes del Niño Jesús y de los angelitos de la peana. En cambio, las imágenes de Velázquez resultan más serias y frías, el rostro de la Virgen es más tosco y la relación de las figuras entre sí es menos cálida, ya que ni María mira al Niño (como sí hace la escultura de Michel) ni el Niño mira a María. En contraposición con esa frialdad, Cosme intenta potenciar otros aspectos para quitar rigidez a la imagen, como es la postura del Niño, mucho más dinámica que en la imagen de Michel, ya que parece lanzarse hacia delante para desprenderse de los brazos de su madre. Sin embargo, este dinamismo no termina de suavizar la frialdad e inexpresividad de las figuras.

Esta misma presencia de la influencia de Michel se puede apreciar en el plegado de las vestiduras. Los pliegues de la imagen de la Virgen del Rosario son agitados y angulosos, con cierta influencia flamenca. Esta influencia flamenca está presente también en las obras de Michel y se debe a que el escultor francés fue discípulo de un escultor flamenco, Luquet. En cambio, en posteriores imágenes de Velázquez, el plegado es más suave y redondeado, más cercano a la influencia clásica. Podemos observarlo en las imágenes que Velázquez realizó en el Oratorio de la Santa Cueva. Si comparamos, por ejemplo, la imagen de la Virgen del Rosario con el relieve de La comunión de san Estanislao de Kostka que se encuentra en ese Oratorio, vemos que las vestiduras de estas figuras muestran unos pliegues más blandos y suaves, con aristas redondeadas y un dinamismo mucho más moderado. 


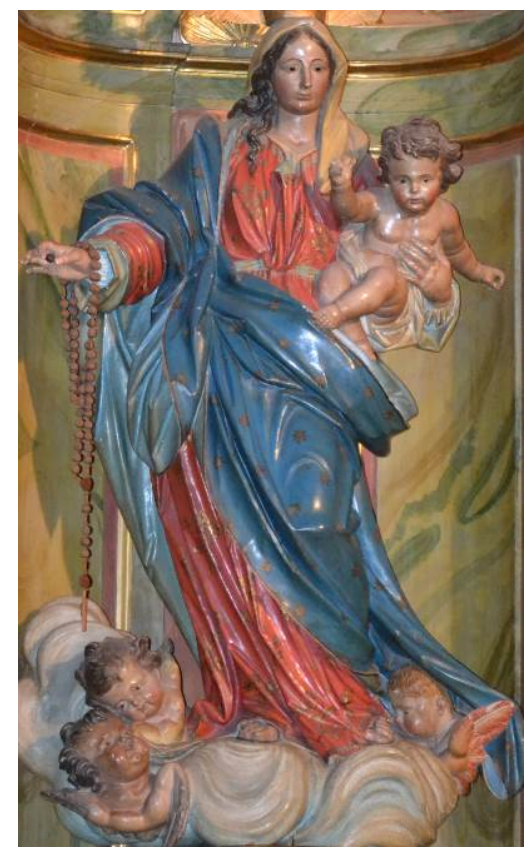

Imagen 3. Virgen del Rosario (detalle). Iglesia parroquial de Navarrete (La Rioja)

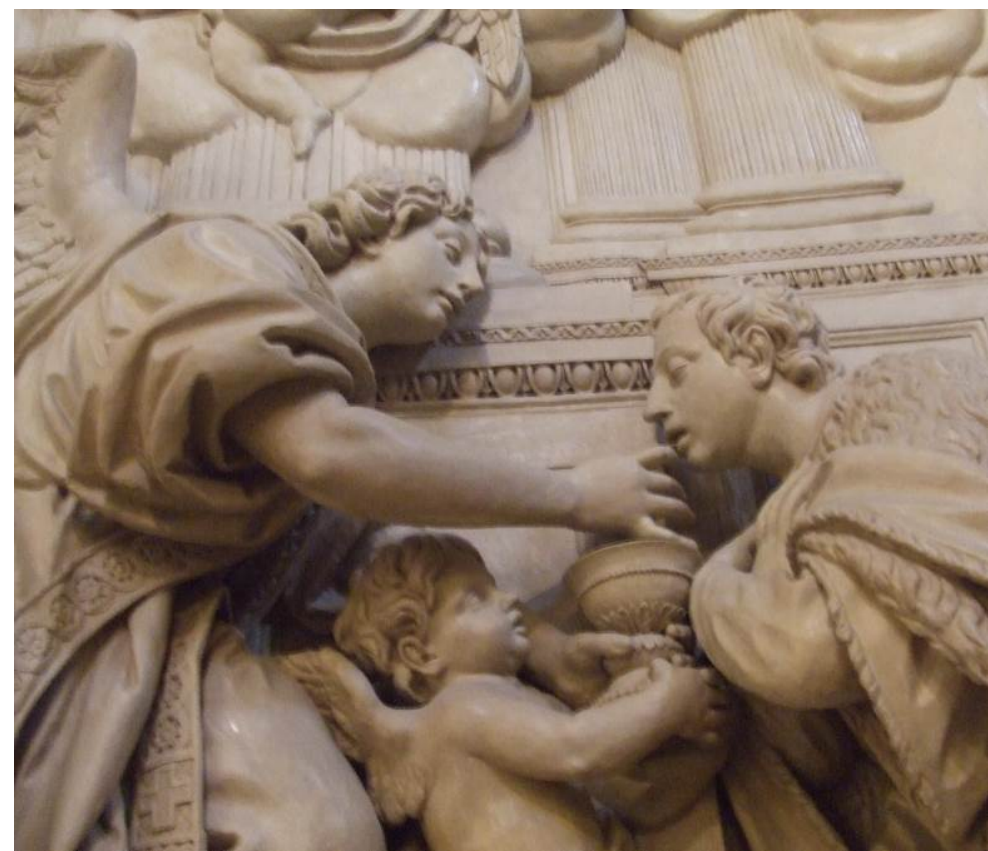

Imagen 4. La comunión de san Estanislao de Kostka (detalle). Oratorio de la Santa Cueva (Cádiz)

Se puede concluir que la imagen de la Virgen del Rosario de Navarrete muestra un estilo mucho más cercano al rococó con influencia flamenca de Roberto Michel mientras que en obras posteriores Cosme Velázquez irá tendiendo hacia un estilo mucho más clasicista por influencia del academicismo.

Sin embargo, Cosme nunca abandonó totalmente la influencia rococó, sino que mantuvo ambas influencias a lo largo de prácticamente toda su obra. Esta característica es 
habitual en los escultores de la generación de Cosme que, aunque educados en el academicismo, no llegaron a eliminar totalmente las influencias barrocas en su obra. Esto se debía a dos razones. Por un lado, a que sus propios maestros seguían una estética más rococó que puramente neoclásica, como hemos visto en el caso de Roberto Michel (aunque lo mismo se podría decir de Juan Domingo Olivieri, Luis Salvador Carmona o Juan Pascual de Mena, por citar a algunos de los profesores de la Academia de este periodo). Por otro lado, los clientes de estos escultores solían ser fundamentalmente iglesias y religiosos que solicitaban imágenes religiosas de carácter devocional, una temática donde era difícil que arraigara el estilo más neoclásico. Por esa razón, la generación de Cosme Velázquez mantuvo esa doble influencia que es tan fácilmente apreciable en las obras de este escultor. Banda y Vargas señalaba que Cosme "no llegó a ser un artista totalmente clásico en la concepción y ejecución de sus obras" ${ }^{97}$ y describía su estilo como de "un correcto clasicismo atenuado por cierta gracia rococó" ${ }^{68}$. En la misma línea, Juan y Lorenzo Alonso de la Sierra señalaban que Cosme "se comporta como un creador de la Ilustración, pues mantiene elementos de tradición barroca inspirados en los grandes maestros franceses e italianos, conjugados con ciertos aires más clasicistas" ${ }^{\text {(99 }}$.

Podemos fijarnos en un pequeño detalle que refleja esta doble influencia: el equilibrio que existe en la obra entre serenidad y movimiento. La Virgen, aunque muestra cierto dinamismo por su marcado contrapposto, se mantiene en general en una postura estable, con una marcada verticalidad. En cambio, el Niño añade un mayor dinamismo por su desequilibrada postura, proyectada hacia delante, como dirigiéndose hacia los espectadores. Es un recurso que Cosme utilizó en otras obras: si volvemos a fijarnos en el relieve de La comunión de san Estanislao de Kostka, vemos que en la Virgen que aparece en la parte superior, entre una gloria de rayos, nubes y querubines, la postura es bastante similar: la Virgen se encuentra sentada mientras el Niño se proyecta hacia adelante, extendiendo los brazos, en este caso hacia san Estanislao.

\footnotetext{
${ }^{67}$ BANDA Y VARGAS, Antonio de la, "Evocación del escultor Cosme Velázquez...”, p. 26.

${ }^{68}$ BANDA Y VARGAS, Antonio de la, "El Academicismo de las Artes...”, p. 132.

${ }^{69}$ ALONSO DE LA SIERRA FERNÁNDEZ, Juan y Lorenzo, "Trabajos en yeso de Cosme Velázquez...", p. 82 .
} 


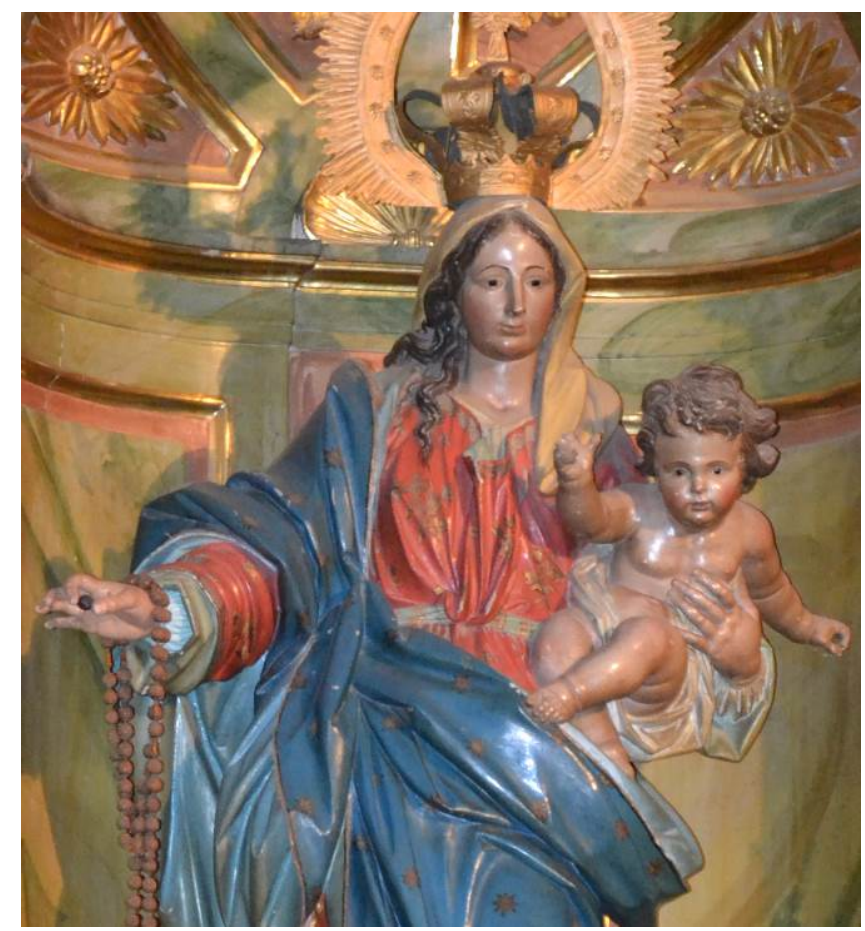

Imagen 5. Virgen del Rosario (detalle). Iglesia parroquial de Navarrete (La Rioja)

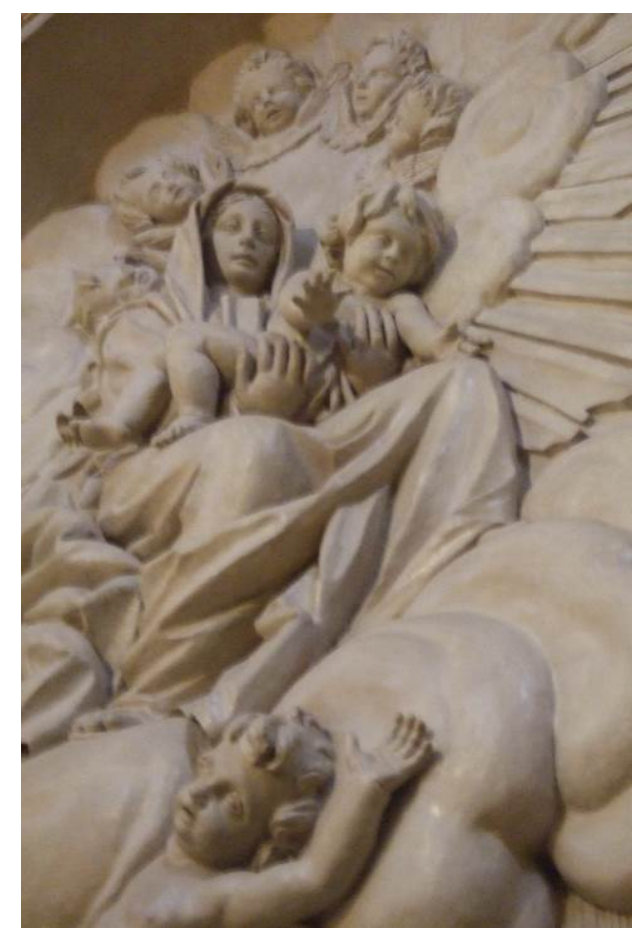

Imagen 6. La comunión de san Estanislao de Kostka (detalle). Oratorio de la Santa Cueva (Cádiz)

El dinamismo del Niño, tanto en uno como en otro caso, requiere un gran dominio de la anatomía infantil, lo cual nos muestra el otro rasgo que indicábamos del estilo de Cosme Velázquez: su maestría en la representación de niños. De hecho, en esta obra contrasta el tratamiento del rostro de la Virgen, algo más tosco y desdibujado con la maestría que el 
escultor demuestra en la talla de las vestiduras y, sobre todo, en la representación de los niños.

Esta maestría posiblemente tenía su origen en su aprendizaje con Roberto Michel, quien también mostraba un gran dominio en la representación de anatomías infantiles ${ }^{70}$. Sin embargo, Cosme tuvo ocasiones de perfeccionar este dominio debido a que fueron muchos los encargos que recibió que incluían la realización de niños, angelitos, querubines, pequeños tritones, etc. Así, una de los primeros encargos destacados que recibió fue la ejecución de los ángeles del retablo de las Niñas de la Paz de Madrid. Posteriormente, realizó muchas otras representaciones infantiles: el Niño Jesús que acompaña a las representaciones de la Virgen y San José, los ángeles realizados para el retablo y la decoración del Oratorio de la Santa Cueva, además de los que aparecen en los relieves eucarísticos de ese mismo templo, los ángeles que decoran los retablos de la iglesia de la Virgen del Rosario, los tritones del ayuntamiento de Cádiz, los ángeles tenantes del Ayuntamiento de Chiclana (en este caso, representados con una edad más avanzada), el ángel plañidero del monumento funerario de Federico Gravina, etc. Banda y Vargas ya señalaba que "lo más numeroso de su producción gaditana son los ángeles, bellamente realizados por cierto" ${ }^{\text {71 }}$.

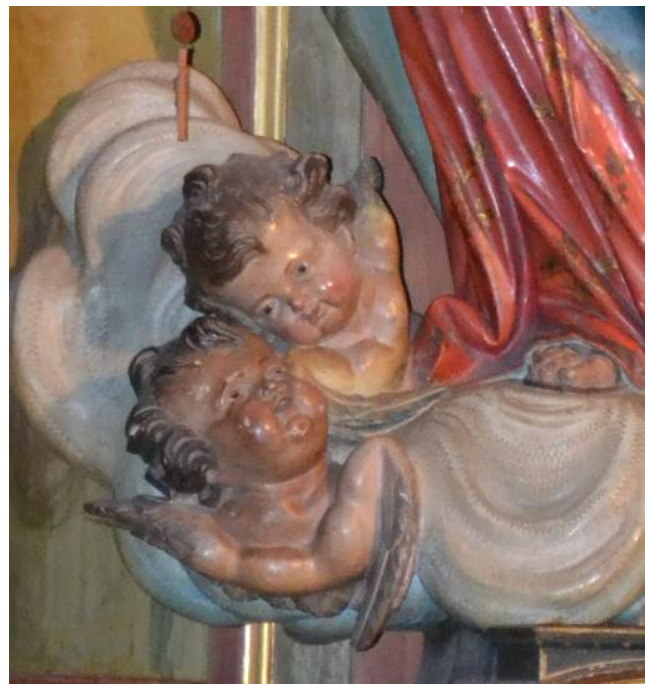

Imagen 7. Virgen del Rosario (detalle). Iglesia parroquial de Navarrete (La Rioja)

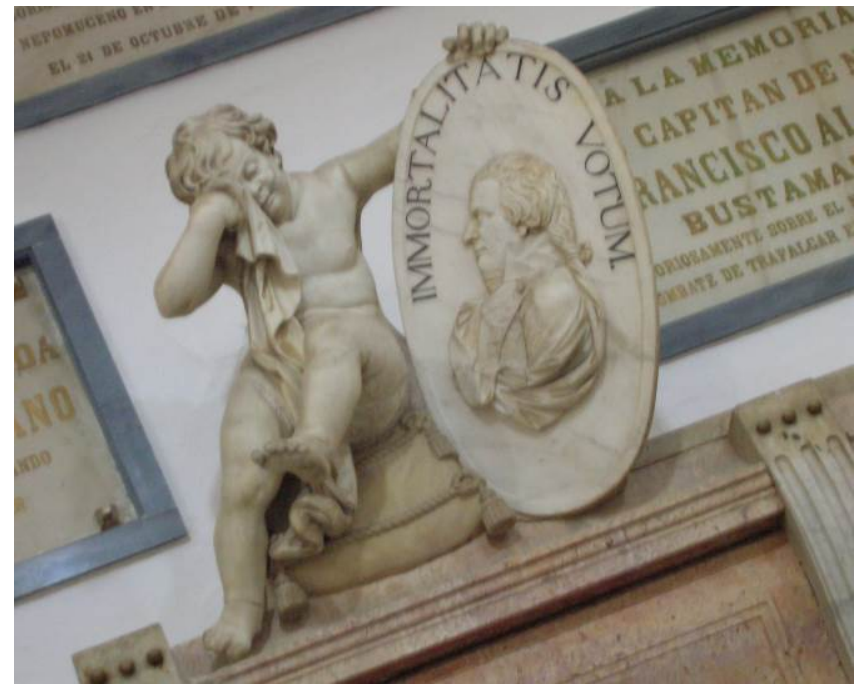

Imagen 8. Sepulcro de Federico Gravina (detalle). Panteón de Marinos Ilustres de San Fernando (Cádiz).

70 TÁRRAGA, María Luisa, “Los estucos de Roberto Michel...”, pp. 315-329.

${ }^{71}$ BANDA Y VARGAS, Antonio de la, "El Academicismo de las Artes...”, p. 132. 


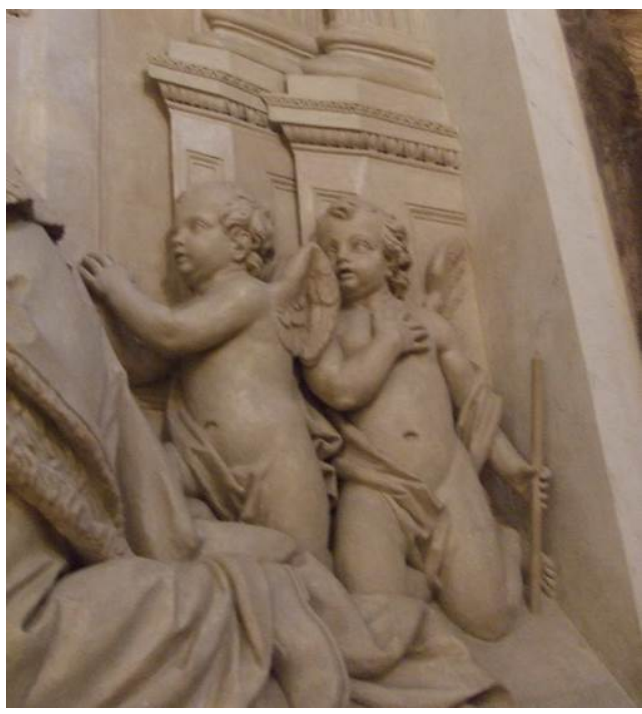

Imagen 9. La comunión de san Estanislao de Kostka (detalle).

Oratorio de la Santa Cueva (Cádiz)

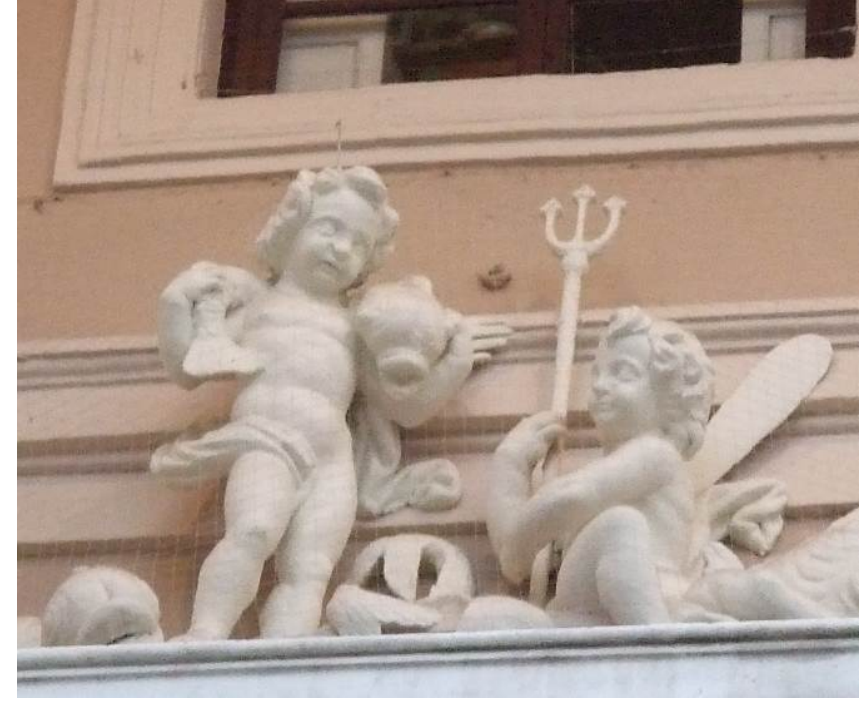

Imagen 10. Tritones. Edificio del Ayuntamiento (Cádiz).

Estos ángeles tendrán unas características comunes, que ya están presentes en la imagen de la Virgen del Rosario. Suelen ser niños de ojos pequeños, mejillas regordetas y cuello ancho. Tienen los cabellos rizados, por lo general con un mechón en la parte delantera que cae sobre la frente, mientras el resto de los rizos se arremolinan en torno a las orejas. Sus expresiones suelen ser comedidas, pero aun así se pueden apreciar diferencias entre unos y otros: los ángeles de la Virgen del Rosario de Navarrete se miran con una divertida complicidad, el niño del monumento funerario de Federico Gravina llora mientras se enjuga las lágrimas con un paño, los ángeles de La comunión de san Estanislao de Kostka contemplan la escena con expresión admirada y reverente y los pequeños tritones del Ayuntamiento de Cádiz intercambian una mirada traviesa.

\section{CONCLUSIONES}

Cosme Velázquez es una figura ilustre para la historia del arte gaditano: considerado introductor del academicismo, maestro con una gran importancia en la transmisión de la formación artística a muchos jóvenes de la ciudad y autor de alguna de las obras más emblemáticas de la localidad. Con este artículo hemos tratado de recopilar la información existente sobre él, así como de ofrecer nuevos datos, sobre todo acerca de su infancia y su formación. También aportamos la identificación de la única obra que parece que realizó para La Rioja, su región natal. Y estudiamos su vinculación con otros riojanos asentados en 
Cádiz, con los cuales parece que tuvo trato pero sin cerrarse, en absoluto, a este círculo de personajes ilustres de origen riojano.

Siguen siendo muchos los datos desconocidos sobre este escultor. Aún desconocemos los motivos por los que empezaría a formarse como artista, si recibió un aprendizaje previo en Logroño o las razones por las que se trasladó a Madrid. Esperamos que futuras investigaciones puedan seguir arrojando luz sobre estos aspectos. 